\title{
Students' Experiences of Emergency Remote Teaching
}

\section{Louis Lafleur}

\section{Ritsumeikan University}

\section{Robert Andrews}

Ritsumeikan University

\section{Trevor Raichura}

Ritsumeikan University

\section{William Fusco}

\section{Ritsumeikan University}

\section{Bjorn Fuisting}

Ritsumeikan University

\section{Reference Data}

Lafleur, L., Andrews, R, Raichura, T., Fusco, W., \& Fuisting, B. (2021). Students' Experiences of Emergency Remote Teaching. In P. Clements, R. Derrah, \& P. Ferguson (Eds.), Communities of teachers \& learners. JALT. https://doi.org/10.37546/JALTPCP2020-16

In this exploratory study, the authors aim to uncover the student experiences of Emergency Remote Teaching (ERT) involving livestream and on-demand lessons for English classes in one faculty of a large private Japanese university during the Covid-19 pandemic. Data were collected from 1178 responses on a mid-semester online survey and follow-up interviews. First- through fourth-year students rated teaching methods and a variety of online tools on their interest level, simplicity of use, and usefulness. The findings from the quantitative and qualitative data revealed that students tended to favour a mixture of on-demand lessons and livestream lessons. Students reported positive feelings about autonomous time-management, and not having to commute to university. However, problems included technical issues, the large array of unfamiliar platforms and delivery methods, a comparatively high workload, and social isolation, particularly among firstyear students. Overall, the data suggests coordinated ERT programmes ought to be streamlined and economical with the use of platforms.

本研究の目的は、コロナ禍における日本の私立大学での英語授業のライブストリームやオンデマンド授業を含む緊急遠隔 教授法 (ERT) の学生体験を明らかにすることである。1年次から4年次の履修生を対象に学期中にオンライン調查とフオロ一 アップインタビューを実施し、1178人から回答を得た。回答者は、教員の指導方法とオンラインツールについて、面白さ、有用 性、使いやすさの視点から評価した。その結果、ライブストリーム授業とオンデマンド授業の組み合わせや、学生自身での時間 管理、通学の回避を好む傾向があることが明らかになった。一方で、多くの受講生がコンピューターの操作技術の問題を抱え ており、慣れないプラットフォームや課題配信方法、課題量の多さや、孤立感といった問題が(特に1回生について) 存在するこ とが分かつた。全体として、ERT活用に当たつては複数のプラットフォームの多用を避け、簡素化すべきであることが示唆され

uring the spring semester of 2020 university students across Japan were faced with the sudden challenge of taking classes online instead of face-to-face due to the spread of Covid-19. This method of instruction differs from typical online learning because the abrupt change in content delivery, plus the lack of student and instructor preparedness, means it is referred to as Emergency Remote Teaching (ERT) (Hodges et al., 2020). Furthermore, online learning and ERT differ in terms of choices made at the student, instructor and administrative level. Online learning curricula are often developed over a period of years, and chosen as a method of instruction by institutions and teachers, as well as a method of learning by students. Alternatively, ERT is implemented in an ad hoc manner, by institutions and instructors who may have little or no experience in online teaching. In addition, the Organization for Economic Cooperation and Development (OECD) reported that Japanese educational institutions and students were far less prepared for online learning than most other OECD countries with 
comparatively low usage of computers at home, and computer technology in schools (OECD, 2020). These potential limitations for students had major implications for instructors' and administrators' selection of content delivery, which in turn, might have impacted students' satisfaction with their courses.

This paper begins with some key differences between online learning and ERT. Then we describe the university response to Covid-19, followed by an explanation of the choices made by instructors regarding whether to teach on-demand or use livestream video conferencing, as well as the selection of specific online teaching tools. Midway through the spring semester of 2020, students completed an online survey on their experiences learning in ERT. Students rated the teaching tools, specifically regarding how interesting, easy to access, and useful the tools were perceived to be. Students also stated what they perceived as advantages and disadvantages of ERT and the methods of content delivery.

\section{Online Learning vs. ERT}

Hodges et al. (2020) warned that "well-planned online learning experiences are meaningfully different from courses offered in response to a crisis or disaster" (paragraph 1). The authors went on to state that it usually takes six to nine months of planning and preparation before an online course is ready for students, and that it takes instructors time to get used to each course. In comparison, ERT is a situation where administrators and instructors are scrambling to transition regular course content to online with tools they may not have used before. There is a limited timeframe to complete planning and preparation with few opportunities for collaboration. Furthermore, online learning development usually involves institutional budgeting that provides platforms and infrastructure that are considered useful for students and instructors. An overview of the differences between ERT and regular online teaching are in Table 1.
Table 1

Online Learning vs Emergency Remote Teaching

\begin{tabular}{ll}
\hline \multicolumn{1}{c}{ Online Learning } & \multicolumn{1}{c}{ Emergency Remote Teaching } \\
\hline $\begin{array}{l}\text { Instructors have experience and } \\
\text { knowledge with online platforms. }\end{array}$ & $\begin{array}{l}\text { Instructors may have no experience with } \\
\text { online instruction and platforms. }\end{array}$ \\
$\begin{array}{l}\text { Delivery methods have been planned and } \\
\text { prepared over a period of months or years. }\end{array}$ & $\begin{array}{l}\text { Delivery methods have to be urgently } \\
\text { chosen. }\end{array}$ \\
Materials are designed for online teaching. & $\begin{array}{l}\text { Materials are designed for classroom } \\
\text { teaching. }\end{array}$ \\
Platforms and infrastructure receive & $\begin{array}{l}\text { Platforms and infrastructure may not be } \\
\text { suitable investment. }\end{array}$ \\
Online learning is chosen by students. & Online lask or budgeted for. \\
\hline
\end{tabular}

\section{University Response to Covid-19}

\section{Background}

In response to Covid-19, the university in this study initially decided to conduct the opening four weeks of the 2020 spring semester online beginning in April. The university administration expected that the first four weeks of class could be conducted asynchronously through the learning management system (LMS) Manaba+R, with a proposed return to classrooms after the Golden Week holiday in May. However, two setbacks occurred. First, on the opening day of online classes, the LMS became overwhelmed by the sudden surge in usage and crashed. Additionally, on April 7, the Japanese government declared a state of emergency. As a result, the university suspended all classes, closed the campus to students, and asked administrative staff and teachers to work from home. On April 21, the university announced that classes would resume May 7 , and the 15-week semester would be reduced to either 12 or 13 weeks depending on the day of the lesson. The university also proposed two ways of providing lesson content, either: (a) asynchronous or on-demand classes with content uploaded to the LMS, or (b) livestream synchronous classes, with instructors using an online video conferencing platform such as Zoom or Skype for Business. The full-time EFL instructors in the business administration faculty (the authors of this paper) sent students a preliminary survey regarding access to computers and Internet connection. On the basis of the survey responses and the fact that the campus was initially inaccessible to students, we decided 
to make most of the EFL content on demand, except for oral communication courses, which we felt would be better taught as livestream classes. We then became coordinators for the compulsory English courses that were taught by international English teachers and created and shared materials using Google Drive for the benefit of other full-time and part-time English teachers. Many of the EFL instructors had some experience using online tools in their classes (blended learning), or had experienced online learning as students. However, this abrupt transition from face-to-face to ERT as a result of the pandemic was distinct from ordinary online learning and was extremely stressful for all involved.

In our department, we faced three challenges. First, we had to create online materials for their curricula that met the university's standards of academic rigor. Secondly, we had to balance concerns of students' lack of access to and technical ability to use computers. Lastly, all instructions had to be clearly written then proofread; links to resources had to be tested; quizzes had to be piloted; introductory and instructional videos had to be recorded; and, teachers unfamiliar with the platforms needed to be taught how to use them.

\section{Choice of Platforms}

Given the difficulty of selecting methods and materials for the courses, we pooled our knowledge of platforms previously used and decided to use Google Forms to make quizzes (as opposed to the university LMS quiz, which instructors had no experience with). We used Flipgrid for uploading video content (particularly for presentations and other speaking activities). We decided to use Quizlet and Eigomemo for vocabulary learning. Eigomemo is a digital flashcard vocabulary software that utilizes Indirect Spaced Repetition (ISR) which combines the concepts of spaced repetition (intervalbased study) and task interleaving (the practice of multiple skills or concepts) (Lafleur, 2020). We selected Zoom as the livestream platform because Zoom included breakout rooms. Because of concerns about privacy and Zoombombing, which has been referred to as a form of harassment and abuse (Lorenz \& Alba, 2020), the university provided all the instructors with licensed Zoom accounts. Teachers set waiting rooms to ensure only known students joined the lessons.

\section{Research Questions}

The purpose of this exploratory study was to investigate the level of student satisfaction with their EFL classes during emergency remote teaching. The researchers set out to answer the following research questions:
RQ1. How satisfied were students with their ERT experience overall?

RQ2. How satisfied were students with specific online tools?

RQ3. What advantages and disadvantages did students perceive of ERT?

\section{Methodology}

\section{Research Methodology}

We sent a questionnaire to all students in the relevant classes via the class news announcement on the university's LMS. Because Japanese English teachers and international English teachers, in general, teach different English courses and are coordinated separately in the university, it was decided for practical reasons to distribute the questionnaire via the international English teachers. At the end of the semester, two students were interviewed to gain further insight into the results.

\section{Participants}

All students in compulsory English classes as well as ten elective classes were asked to participate using a voluntary response sample method, meaning students did not have to answer the survey but were encouraged to do so (Jupp, 2006). All data were collected with the informed consent of students in accordance with institutional ethical guidelines. Students were informed in English and in Japanese that the survey was optional, anonymous, and that the decision to complete the survey or not had no bearing on their grades. In addition, students were informed that their answers would be collected for research and professional development. In total, around 1,600 students in 82 classes were invited to participate. After accidental/duplicate submissions were removed, 1,178 valid responses were obtained from 1,153 different students (multiple submissions were retained only for students who were enrolled in more than one class covered by the questionnaire) for an answer rate of around $73 \%$.

\section{Questionnaire}

A bilingual, English and Japanese, questionnaire was made in Google Forms. The Japanese translations were written by the authors and checked by two L1 Japanese speakers for accuracy. We designed the questionnaire so that students answered only the relevant questions for the classes they took and the tools used in those classes. It consisted of four demographic questions, 15 questions about the tools, and four questions about their overall online learning experiences. The questionnaire focused 
on the use of the pre-recorded videos (videos made by the instructors), Google Forms, Flipgrid, Quizlet/Eigomemo (vocabulary study), Manaba+R (LMS), and Zoom/Skype (live-streamed video). Students were first asked if their class used a specific tool, such as if the teacher posted an "Opening video" to introduce the weekly class. If the student answered "yes", then a follow-up question related to the topic was asked. Using a 5-point Likert scale, students rated how easy it was to access the tool, how useful the tool was, and how interesting they found it. Students were then given an optional open-ended question where they could state any general comments regarding how they believed the tool could be used better. If students answered that the teacher had not used a given tool, then they were asked if they would have liked their teacher to have used the relevant tool. Next, students were asked to rate the overall online experience on a 10-point Likert scale (to provide participants more nuanced options) as well as check what they had enjoyed and not enjoyed about online learning. Finally, the students had the option to add any final comments, thoughts or ideas. The link to the Google Forms questionnaire was emailed to the students in June. Appendix A shows the questions asked for one of the online tools as well as the questions related to the overall online learning experience.

\section{Interviews}

After completing the questionnaire data collection, the data were re-sequenced from low to high satisfaction to identify potential candidates to participate in individual semi-structured interviews. We wanted to interview students who had indicated a highmid- and low-level of overall satisfaction of online learning (based on the final section in the questionnaire) in order to further explore what the reasons for their satisfaction levels were. Ten students with low-, mid- and high-levels of overall satisfaction, for a total of 30 participants, were contacted via their institutional email address to arrange online interviews. However, only two students agreed to take part in the interviews. The interviews were conducted in English by two of the authors via Zoom/Skype and were first recorded and later transcribed. The qualitative data obtained from both the interviews and the survey were further coded and analyzed with similar responses indexed to identify themes in student perceptions of the online tools surveyed (Parson \& Brown, 2002)

\section{Results}

In order to assess the questionnaire's Likert-scale data reliability and uncover statistical variances, we calculated Cronbach's alpha $=.986$ (Table 5 items), Pearson's $r$, mean, and standard deviation values using Google Sheets. However, Cronbach's alpha was not calculated for data related to Tables 2 and 3 as internal consistency could not be established from a single 10-point rating scale item.

Table 2

Overall Satisfaction by Collegiate Year

\begin{tabular}{lccccccccccc}
\hline $\begin{array}{c}\text { Groups } \\
(\mathrm{n})\end{array}$ & 1 & 2 & 3 & 4 & 5 & 6 & 7 & 8 & 9 & 10 & $M$ \\
\hline 1st year & 34 & 39 & 68 & 92 & 139 & 100 & 117 & 90 & 27 & 29 & $M=5.51$ \\
$(735)$ & $4.6 \%$ & $5.3 \%$ & $9.3 \%$ & $12.5 \%$ & $18.9 \%$ & $13.6 \%$ & $15.9 \%$ & $12.25 \%$ & $3.7 \%$ & $3.95 \%$ & $S D=2.22$ \\
2nd year & 13 & 15 & 30 & 24 & 52 & 57 & 50 & 56 & 23 & 11 & $M=5.88$ \\
$(331)$ & $3.9 \%$ & $4.55 \%$ & $9.1 \%$ & $7.3 \%$ & $15.7 \%$ & $17.2 \%$ & $15.1 \%$ & $16.9 \%$ & $6.95 \%$ & $3.3 \%$ & $S D=2.23$ \\
3rd year & 3 & 7 & 10 & 8 & 13 & 14 & 19 & 9 & 7 & 1 & $M=5.56$ \\
$(91)$ & $3.3 \%$ & $7.7 \%$ & $11 \%$ & $8.8 \%$ & $14.25 \%$ & $15.4 \%$ & $20.85 \%$ & $9.9 \%$ & $7.7 \%$ & $1.1 \%$ & $S D=2.21$ \\
4th year(+) & 0 & 1 & 1 & 1 & 0 & 4 & 1 & 3 & 5 & 5 & $M=7.57$ \\
$(21)$ & & $4.8 \%$ & $4.8 \%$ & $4.8 \%$ & & $19 \%$ & $4.8 \%$ & $14.3 \%$ & $23.8 \%$ & $23.8 \%$ & $S D=2.40$ \\
Total & 50 & 62 & 109 & 125 & 204 & 175 & 187 & 158 & 62 & 46 & $M=5.66$ \\
$(1178)$ & $4.2 \%$ & $5.3 \%$ & $9.3 \%$ & $10.6 \%$ & $17.3 \%$ & $14.85 \%$ & $15.9 \%$ & $13.4 \%$ & $5.25 \%$ & $3.9 \%$ & $S D=2.24$ \\
\hline
\end{tabular}

Note. (10-point Likert scale, 1 = poor (satisfaction), $10=$ excellent (satisfaction) $M=$ Mean, $S D=$ Standard Deviation

Pearson's $r(1176)=.09, p=.001$ 
Table 3

Class Modality Satisfaction Comparison

\begin{tabular}{lccccccccccc}
\hline $\begin{array}{c}\text { Modality } \\
\text { (n) }\end{array}$ & 1 & 2 & 3 & 4 & 5 & 6 & 7 & 8 & 9 & 10 & $M$ \\
\hline On demand & 47 & 58 & 92 & 100 & 164 & 155 & 160 & 121 & 49 & 36 & $M=5.59$ \\
$(982)$ & $4.8 \%$ & $5.9 \%$ & $9.35 \%$ & $10.2 \%$ & $16.7 \%$ & $15.8 \%$ & $16.3 \%$ & $12.3 \%$ & $5 \%$ & $3.65 \%$ & $S D=2.25$ \\
Live & 1 & 2 & 7 & 7 & 13 & 5 & 11 & 8 & 4 & 3 & $M=5.84$ \\
$(61)$ & $1.6 \%$ & $3.3 \%$ & $11.5 \%$ & $11.5 \%$ & $21.3 \%$ & $8.2 \%$ & $18 \%$ & $13.1 \%$ & $6.6 \%$ & $4.9 \%$ & $S D=2.18$ \\
Mixed & 2 & 2 & 10 & 18 & 27 & 15 & 16 & 29 & 9 & 7 & $M=6.13$ \\
$(135)$ & $1.5 \%$ & $1.5 \%$ & $7.4 \%$ & $13.3 \%$ & $20 \%$ & $11.1 \%$ & $11.8 \%$ & $21.5 \%$ & $6.7 \%$ & $5.2 \%$ & $S D=2.10$ \\
Total & 50 & 62 & 109 & 125 & 204 & 175 & 187 & 158 & 62 & 46 & $M=5.66$ \\
$(1178)$ & $4.2 \%$ & $5.3 \%$ & $9.3 \%$ & $10.6 \%$ & $17.3 \%$ & $14.85 \%$ & $15.9 \%$ & $13.4 \%$ & $5.25 \%$ & $3.9 \%$ & $S D=2.24$ \\
\hline
\end{tabular}

Note. (10-point Likert scale, 1 = poor (satisfaction), $10=$ excellent (satisfaction) $M=$ Mean, $S D=$ Standard Deviation

Pearson's $r(1176)=.08, p=.005$

Table 4

Online Tools/Software In-Class Implementation

\begin{tabular}{|c|c|c|c|c|c|}
\hline Tool & Type & Yes & Sometimes & No & $\mathrm{n}^{1}$ \\
\hline Manaba+R & $\begin{array}{l}\text { Learning Management } \\
\text { System }\end{array}$ & $1071(95.9 \%)$ & & $46(4.1 \%)$ & 1117 \\
\hline Google Forms & Textbook tasks etc... & $759(67.9 \%)$ & $108(9.7 \%)$ & $250(22.4 \%)$ & 1117 \\
\hline $\begin{array}{l}\text { Pre-recorded } \\
\text { videos }\end{array}$ & Teacher videos etc... & $419(37.5 \%)^{2}$ & $144(12.9 \%)$ & $544(49.6 \%)$ & 1117 \\
\hline Flipgrid & $\begin{array}{l}\text { Pre-recorded student } \\
\text { videos }\end{array}$ & $283(25.3 \%)$ & $121(10.8 \%)$ & $713(63.8 \%)$ & 1117 \\
\hline $\begin{array}{l}\text { Quizlet/ } \\
\text { Eigomemo }\end{array}$ & Vocabulary software & 348 (31.2\%) & & $769(68.8 \%)$ & 1117 \\
\hline Zoom/Skype & Live streaming lesson tool & $120(10.2 \%)$ & $127(10.8 \%)$ & $931(79 \%)$ & 1178 \\
\hline
\end{tabular}

Note. ${ }^{1}$ Some questions here may have been skipped when deemed non-applicable by a participant. Note. ${ }^{2} 80$ (7.2\%) of the responses attributed here to "Yes" were entered as "Most of the time."
Table 5

Online Tool Satisfaction (Usability, Interest and Usefulness Combined)

\begin{tabular}{|c|c|c|c|c|c|c|c|}
\hline Tool & $\mathrm{n}$ & 1 & 2 & 3 & 4 & 5 & $\begin{array}{l}M \\
S D\end{array}$ \\
\hline Manaba+R & 3180 & $72(2.3 \%)$ & $189(5.9 \%)$ & $833(26.2 \%)$ & 875 (27.5\%) & $1211(38.1 \%)$ & $\begin{array}{l}M=3.93 \\
S D=1.04\end{array}$ \\
\hline $\begin{array}{l}\text { Pre- } \\
\text { recorded } \\
\text { videos }\end{array}$ & 1662 & 27 (1.6\%) & $144(8.7 \%)$ & $436(26.2 \%)$ & 488 (29.4\%) & 567 (34.1\%) & $\begin{array}{l}M=3.86 \\
S D=1.04\end{array}$ \\
\hline $\begin{array}{l}\text { Zoom/ } \\
\text { Skype }\end{array}$ & 735 & $22(3 \%)$ & 48 (6.55\%) & $273(37.15 \%)$ & 167 (22.7\%) & 225 (30.6\%) & $\begin{array}{l}M=3.71 \\
S D=1.06\end{array}$ \\
\hline $\begin{array}{l}\text { Google } \\
\text { Forms }\end{array}$ & 2586 & $121(4.7 \%)$ & $212(8.2 \%)$ & 801 (30.95\%) & 669 (25.85\%) & 783 (30.3\%) & $\begin{array}{l}M=3.69 \\
S D=1.12\end{array}$ \\
\hline Flipgrid & 1206 & $92(7.6 \%)$ & 153 (12.7\%) & $365(30.3 \%)$ & 317 (26.3\%) & $279(23.1 \%)$ & $\begin{array}{l}M=3.45 \\
S D=1.19\end{array}$ \\
\hline $\begin{array}{l}\text { Quizlet/ } \\
\text { Eigomemo }\end{array}$ & 1023 & $86(8.4 \%)$ & 135 (13.2\%) & $325(31.8 \%)$ & $256(25 \%)$ & 221 (21.6\%) & $\begin{array}{l}M=3.38 \\
S D=1.20\end{array}$ \\
\hline
\end{tabular}

Note. Some questions here may have been skipped when deemed non-applicable by a participant.

(5-point Likert scale, 1 = not satisfied, $5=$ highly satisfied) $M=$ Mean, $\mathrm{SD}=$ Standard Deviation, Cronbach's alpha $=.986$

\section{Discussion}

The first research question of this study was how satisfied students were with their ERT experience overall. The questionnaire's 10-point rating scale item shows that the students who were in the fourth year and beyond were the most satisfied while those in their first year were the least (see Table 2). First-year students' data and comments suggest their discontent about missing opportunities to meet and form relationships with their classmates. Satisfaction generally increased with higher collegiate years as results indicate a low positive correlation $r(1176)=.09, p=.001$. In terms of class modalities and overall satisfaction, students who answered the survey on behalf of a mixed online class with both live and on-demand coursework were the most satisfied. Students who answered on behalf of an on-demand class were the least satisfied with their experience. (see Table 3). Student satisfaction steadily increased across the three modalities from on demand to live classes 
to mixed modality classes with results indicating a low positive correlation, $r(1176)=.08$ $p=.005$. We attribute this to the fact that a mixture of on demand and livestream classes provided students with a certain degree of scheduling flexibility and social interaction, which was indicated as important to them.

The second research question was how satisfied students were with specific online tools. Not all tools were utilized equally by all the students (see Table 4). The university's official, yet not mandatory, LMS Manaba+R was the most utilized tool for teaching online classes. It was uncommon for lecturers to use alternate LMS such as Edmodo, Google Classroom or organize their classes through email. As most classes were of an online on-demand nature, Zoom/Skype were not utilized on a wide scale. In terms of satisfaction, the students expressed higher satisfaction with Manaba+R, pre-recorded videos and Zoom/Skype, and lower satisfaction with Google Forms, Flipgrip and Quizlet/ Eigomemo (see Table 5). Although Zoom/Skype can be a useful tool for live online classrooms, it should be noted that pre-recorded videos outscored Zoom/Skype in all three categories (Usability, Interest, and Usefulness), and even surpassed Manaba $+\mathrm{R}$ in terms of Interest. Although Quizlet/Eigomemo on average scored the lowest, students did find it more useful for their EFL learning than other software such as Flipgrip. Other than serving its purpose to enable students to record their spoken production for on-demand classes, Zoom/Skype was deemed better in terms of usability, interest, and usefulness than Flipgrid.

The third research question in this study was what advantages and disadvantages did students perceive of ERT. Students reported positive feelings about not having to commute to campus (67\%), autonomous time-management (60\%), and not having to wake up early (53\%). However, the majority of feedback related to the disadvantages of ERT. The qualitative data collected revealed three main themes (see Appendix B): frustration with technical issues, a desire for content in Japanese, and a desire for social interaction. While comments related to negative aspects of the online format were wide-ranging, the most common centered around technical issues related to Internet connectivity or the use of online tools as well as confusion about how to complete coursework. The most often cited technical issues were a difficulty connecting to Zoom and difficulty hearing the teacher during Zoom lessons. Students expressed a preference for assignments to be posted on Manaba+R. Other online tools were criticized due to being confusing, or because of difficulty in keeping track of progress, particularly when using Google Forms.

Based on student comments, it appears that a lack of Japanese language instruction compounded the difficulty in adjusting to the online format. Comments relating to the language medium for instruction were situated mainly but not exclusively around "Manaba+R" and "Pre-recorded videos." (Table 5) Students would likely have preferred teachers to post bilingual instructions and make bilingual videos. The following comments are representative: "I can understand it in English alone, but if I have a Japanese translation, it's easy to work on classes and assignments." and "I'm not sure what to do because it's all in English."

Students expressed a desire for social interaction. Although the comments reflect upon a teaching period prior to widespread use of Zoom lessons, there is a clear indication that students missed the social aspect of face-to-face lessons. Social interaction was touched upon by both interviewees, with one stating: "I can't improve my communication skills and [can't] get new friends. So, maybe... In [the] last year, I have some friends to hang out [with] and eat with but in this semester I can't [meet] my friends and use enough English communications skill[s] maybe. It is the biggest difference, I think." As a further illustration, although the quantitative data suggests that Flipgrid was not popular with students, a few students perceived its value in promoting student engagement and interaction, as stated by an interviewee, "I find it quite useful. We constantly use Flipgrid every week. ... It was good to see other students were talking."

Although it is not possible to represent all students, the following interview response possibly summarizes the general feeling of many students during the semester: "Every teacher uses different forms of submissions, so sometimes I get confused on what to do. So, I wish every professor used [the] same platforms." The other interviewee also corroborated, "I don't [think the] quality of the class went bad or anything like that. I just felt as [though the] format is completely different, and sometimes I felt as though I was doing more work than [a usual semester's] classes."

\section{Conclusion}

The results of this exploratory study inspired the following considerations for possible implementation in ERT. In terms of class modality, a mixture of on-demand and livestream classes should be the preferred approach for ERT as it provides students with a certain degree of scheduling flexibility and social interaction. In addition, including prerecorded videos is highly recommended as they are popular with students because they are less demanding than other tools, and allow a certain amount of interaction with the instructor in an easy replayable format. Furthermore, additional online tools should not be introduced unless they serve a purpose to reach course goals. Any new online tools should be carefully introduced with pre-recorded videos to ensure successful utilization. 
Furthermore, students with lower English proficiency should be given access to how-to guides for the utilized tools in their L1 as much as possible. Lastly, course coordinators should consider the time needed for students to adapt to an ERT environment while setting course objectives.

There were a number of limitations to this study. For example, the purpose of the questionnaire was to focus only on English classes; students may have also reported on wider concerns with other courses as well. This is unsurprising given that students may have been disappointed with the impact of Covid-19 on other parts of their university lives. Also, as in other research (Crick et al., 2020) related to attitudes to ERT, this study's questionnaire may capture some of the more negative reactions to abruptly going online (the questionnaire was sent midway through the spring semester) and these negative reactions may reflect dissatisfaction with an unfamiliar or unexpected learning modality. Attitudes may have changed as students become more used to this form of learning.

Covid-19 presented an extraordinary challenge to students and learners alike, and given that 2021 is likely to continue with some form of remote teaching, we offer six major recommendations to increase student satisfaction with ERT:

1. Use a mixture of on demand and livestream.

2. Introduce on-demand content with pre-recorded video(s).

3. Explain clearly the rationale for the use of each tool.

4. Clearly instruct students how to use each tool.

5. Consider using L1 interfaces for tools and instruction for lower-level students.

6. Reduce the number of assessed assignments for ERT.

We have come to the conclusion that the overwhelming majority of the students rose to the challenge of the pandemic and attempted to comply with the emergency remote teaching situation. Instructors, likewise, ought to do what they can to maintain a learning situation that benefits students socially and academically and it is hoped that this study can provide insight into students' perception of ERT.

\section{Bio Data}

Louis Lafleur has been teaching at Ritsumeikan University for four years, and has interests in vocabulary acquisition, cognitive psychology and gamified learning.

Robert Andrews has been teaching at Ritsumeikan University for three years, and has interests in writing, critical thinking and learning management systems.

Trevor Raichura has been teaching at Ritsumeikan University for three years, and has interests in vocabulary acquisition and the role of $\mathrm{L} 1 \mathrm{in} \mathrm{L} 2$ acquisition.

William Fusco has been teaching at Ritsumeikan University since April of 2020. His current interests are project-based language teaching and situated learning.

Bjorn Fuisting is an Associate Professor at Ritsumeikan University, Japan. His research interests include peer review, extensive reading and teacher professional identity.

\section{Acknowledgments}

The authors are grateful to the reviewers, copyeditors and journal editors for their advice and assistance.

\section{References}

Crick, T., Knight, C., Watermeyer, R., \& Goodall, J. (2020). The impact of COVID-19 and "emergency remote teaching" on the UK computer science education community. UKICER '20: United Kingdom \& Ireland Computing Education Research Conference. (September 2020), 31-37. https://doi.org/10.1145/3416465.3416472

Hodges, C., Moore, S., Lockee, B., Trust, T., \& Bond, A. (2020). The difference between emergency remote teaching and online learning. Educause Review. Retrieved January 7, 2021, from https:// er.educause.edu/articles/2020/3/ the-difference-between-emergency-remote-teaching-andonline-learning\#: :text=In\%20contrast\%20to\%20experiences\%20that,mode\%20due\%20to\%20 crisis\%20circumstances

Jupp, V. (2006). The Sage dictionary of social research methods. Sage. https://doi. org/10.4135/9780857020116

Lafleur, L. (2020). The indirect spaced repetition concept. Vocabulary Learning and Instruction, 9 (2), 9-16. https://doi.org/10.7820/vli.v09.2.lafleur

Lorenz, T., \& Alba, D. (2020). 'Zoombombing' becomes a dangerous organized effort. The New York Times. Retrieved January 7, 2021, from https://www.nytimes.com/ 2020/04/03/technology/ zoom-harassment-abuse-racism-fbi-warning.html 


\section{JALT2020}

COMMUNITIES OF

OECD (2020), School education during Covid-19: Were teachers and students ready? Country Note Japan. Retrieved January 7, 2021, from http://www.oecd.org/education/Japan-coronaviruseducation-country-note.pdf

Parson, R. D., \& Brown, K. S. (2002). Teacher as reflective practitioner and action researcher. Wadsworth/Thomson Learning.

\section{Appendix A}

Questionnaire Sample Questions

(Please note that this questionnaire was originally conducted via Google forms, so formatting is not representative.)

\section{On-Demand Class Contents - Flipgrid オンデマンド:Flipgrid}

*Required

1. Does your teacher use Flipgrid? 先生は, 授業でFlipgridを利用していますか。* Mark only one oval.

$\begin{array}{ll}\text { Yes } & \text { Skip to question } 3 \\ \text { Sometimes } & \text { Skip to question } 3\end{array}$

No

2. Would you like your teacher to use Flipgrid in your class? 先生にFlipgridを使ってほしい ですか? Mark only one oval.

Yes

No

Maybe

I don't know

Other
3. How easy is it to access Flipgrid? Flipgridへのアクセスはいかがですか。* Mark only one oval.

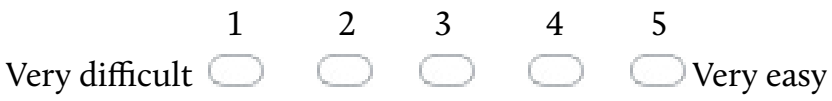

4. How useful are Flipgrid tasks? Flipgridは役に立ちますか。 Mark only one oval.

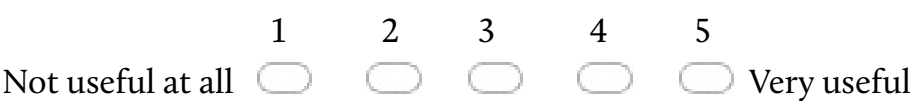

5. How interesting are Flipgrid tasks? Flipgridは興味深いですか。*Mark only one oval.

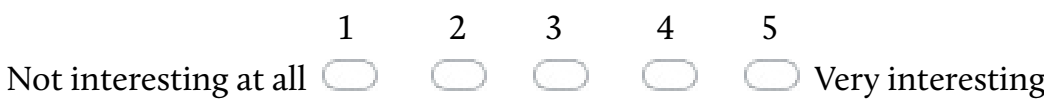

6. Comments on how to improve Flipgrid tasks. Flipgridの感想、改善法、要望があれば教 えてください。

Online Learning-Overall experience オンライン学習:総合

1. How would you rate your overall online experience this semester? 今学期のオンライン の授業を総合的に評価してください。*Mark only one oval.

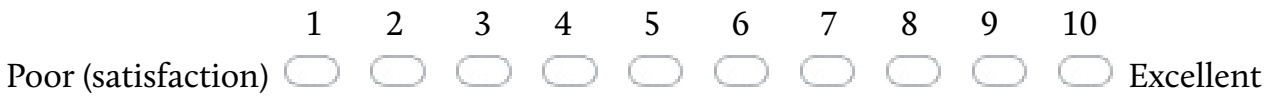

2. What have you enjoyed about online learning? オンライン学習の良いところは?* Tick all that apply.

The workload is fairly light 学習する量が比較的少ない

I can create my own schedule for myself 自分で決めたスケジュールで学習できる

I don't have to commute to school 通学しなくて済む

I don't have to wake up early 早起きしなくて済む

I don't need to interact with my teacher and classmates

先生やクラスメイトとやりとりしなくて済む 


\section{JALT2020}

COMMUNITIES OF
TEACHERS \& IEARNERS
I can try out new technology / applications

新しいテクノロジー,ソフト,アプリなどを試すことができる

I haven't enjoyed it at all! 全く良いところはない

Other:

3. What have you NOT enjoyed about online learning? オンライン学習の良くないところ は?* Tick all that apply.

The workload is heavier than I expected 思ったより学習量が多い

It is difficult to balance my schedule 自分でスケジュールを決めるのは難しい

Every teacher's way of doing things is different, so it is hard to follow 先生によってやり方が異なるため, 理解するのが難しい

I I cannot communicate with my classmates and teachers face-to-face クラスメイトや先生とコミュニケーションを十分に取れない

- There are too many different platforms (Flipgrid, Google, Manaba, Quizlet, etc) and it is hard to keep track of everything フリップグリッドやマナバなど学習方法が多 すぎるため, 全てを把握するのが難しい

There are many technical problems 技術上の問題が多い

I enjoy everything about online learning! No complaints! オンライン学習についての不満点は何もない

\section{Other:}

4. If you have any final comments, thoughts, or ideas you would like to share, please do so here. コメント, 意見, 要望などがあれば教えてください。

\section{Appendix B}

Qualitative Data Themes with Notable Student Comments

Manaba+R

- Manaba+R is easier to understand than other tools:

"Every week's tasks are posted on course news so it is very convenient to do the work."

"When we submit an assignment, I would like to submit it on Manaba+R because it is much easier."

- Written Instructions unclear:

"I'm not sure what to do because it's all in English"

Pre-recorded Videos

- A sense of reassurance:

"It's good to see [the] teacher's face and I'm [satisfied] with the videos. If it's possible to explain about the content (teach us the content of [the] textbook, [that] would be better!"

- Content that is easier to understand:

"There are some places where I can't understand English, so I would like you to speak a little slowly."

- Content in Japanese:

"I can understand it in English alone, but if I have a Japanese translation, it's easy to work on classes and assignments."

Zoom/Skype

- Interference due to technical issues:

"There are quite a few times when it's difficult to connect and you can't hear your voice."

"Sometimes I can't enter the Zoom, but I don't know the reasons."

"When my family uses a microwave oven, the Internet connection is interrupted and Zoom stops..." 


\section{JALT2020}

COMMUNITIES OF
TEACHERS \& IEARNERS

Google Forms

- Unable to confirm if form has been submitted:

"Sometimes I cannot see if I have submitted correctly."

- Perceived troubles with answers:

"Even if you give the same answer as the correct answer, it is often not the correct

answer."

- Unable to save entries:

"If I go to the previous page, all the data will be lost."

- Unable to understand/answer questions:

"It is sometimes difficult to understand the meaning of questions."

Flipgrid

- Anxiety making videos:

"...we should provide our face [film ourselves] for many [people to see]. I don't like it, but it is very helpful for studying."

- Difficulty uploading/accessing:

"Uploading videos takes a lot of time."

"I think it is (a) little hard to access on Flipgrid."

- Social interaction:

"I'm happy that I can see my classmates' faces on Flipgrid!!"

"It was interesting to see the self-introduction video of the class members."

\section{Quizlet/Eigomemo}

- Usefulness:

"I sometimes feel it (is) hard, but I think it helps me study English."

"Very difficult, but very useful."

- Uncertain about completion:

"I'm not sure if I actually completed the task on Quizlet since it doesn't say anything."

"I want to know how I can check whether I (completed) Quizlet or not." 